\title{
An Analysis on the Factors Affecting the Satisfaction Degree of the System of the Ideological and Political Curriculum in General Education in Chinese Junior Colleges of Science and Technology
}

\author{
Jing $\mathrm{Li}^{1}$, Xiaoqin Chen ${ }^{1}, \mathrm{Li} \mathrm{You}^{2}$ and Qiqiang $\mathrm{Chen}^{3}$ \\ ${ }^{1}$ General Education Department, Sichuan Post and Telecommunication College, Chengdu, China \\ ${ }^{2}$ Guobao Life Insurance Co., Ltd, Chengdu, China \\ ${ }^{3}$ Department of Economic and Trade Management, Yibin Vocational and Technical College, Yibin, China
}

\begin{abstract}
This paper first briefly analyzes the status of the system of the ideological and political curriculum (SIPC) in Chinese junior colleges of science and technology, then analyzes the factors affecting the satisfaction degree of SIPC in general education in Chinese junior colleges of science and technology based on 5 dimensions consisting of the philosophy of the ideological and political curriculum (PIPC), the content of the ideological and political curriculum (CIPC), the teachers of the ideological and political curriculum (TIPC), the achievements of the ideological and political curriculum (AIPC) and the relevant investigation of the ideological and political curriculum (RIPC). Through the descriptive statistic analysis, the correlation analysis and the regression analysis on the questionnaire survey, it is found that CIPC, TIPC and PIPC are the 3 factors affecting the satisfaction degree of SIPC from the least to the greatest influence degree respectively. Therefore, not only should be the importance of CIPC attached to general education in Chinese junior colleges of science and technology but also should be TIPC and PIPC focused on, what's more, the other dimensions should be further applied to the analysis on SIPC, in order to improve the satisfaction degree of SIPC in general education of Chinese junior colleges of science and technology.
\end{abstract}

\section{Introduction}

In general education in Chinese junior colleges of science and technology, the ideological and political curriculum is an integrated part which plays an irreplaceable role for which other curricula can't substitute in the ideological and moral education and in the political education. In terms of the hierarchy compared with the undergraduate colleges and in terms of the classification compared with the arts colleges, the system of the ideological and political curriculum (SIPC) in general education in Chinese colleges of science and technology shows the lowest status. This paper is to analyze the factors affecting the satisfaction degree of SIPC based on 5 dimensions --- PIPC, CIPC, TIPC, AIPC and RIPC and through the analysis of descriptive statistics, correlation and regression. Finally, this paper makes some conclusions from these analyses.

\section{The status of SIPC in general education in Chinese junior colleges of science and technology}

From the empirical analysis, for the hierarchy, undergraduate colleges more stress the comprehensive qualities and for the classification, arts colleges more focus on humane qualities. Subjectively, although the importance of the ideological and political curriculum is the same to all the Chinese colleges in which the ideological and political curriculum is set as the compulsory subject, objectively, the difference of hierarchy and classification leads to the different status of SIPC in general education in different colleges.

In Figure 1, the horizontal axis representing the hierarchy of colleges and the vertical axis representing the classification of colleges divide Chinese colleges into 4 combinations --- junior colleges of science and technology I, undergraduate colleges of science technology II, junior colleges of arts III, undergraduate colleges of arts IV. On the whole, the status of the ideological and political curriculum in general education is combinedly determined by the hierarchy and the classification generally with the improving trend from junior colleges to undergraduate colleges and from the colleges of science and technology to the arts colleges. The trend of the dotted line with arrow shows the improving status of SIPC in general education in Chinese colleges of different hierarchy and different classification. It is found that generally the status of SIPC in the 4 kinds of colleges is that the status of undergraduate is higher than junior colleges, arts colleges higher than the colleges of science and technology. The status is the highest for 
the undergraduate colleges of arts and the lowest for the colleges of science and technology.

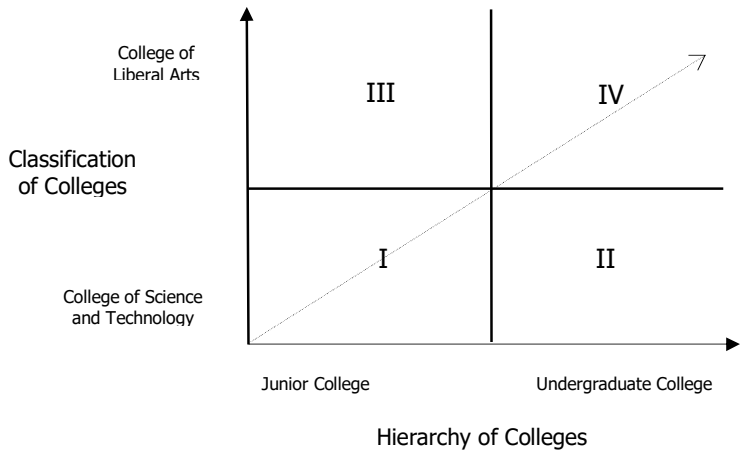

Figure 1. The Status of SIPC in Chinese Colleges of Different Level and Different Classification.

\section{The regression analysis on the satisfaction degree of SIPC in general education in Chinese colleges of science and technology}

In priori, compared with the undergraduate colleges and with the arts colleges, the status of SIPC in general education in the colleges of science and technology can reflect the degree of approval of SIPC in general education in the colleges of science and technology, which can be analyzed by the satisfaction degree of SIPC in general education in Chinese colleges of science and technology.

\subsection{Questionnaire survey}

\subsubsection{Questionnaire setting}

In this paper, the questionnaire setting of SIPC in general education of Chinese colleges of science and technology is composed of 5 dimensions --- PIPC, CIPC, TIPC, AIPC and RIPC. Every dimension includes several questions which are seen in Table 1.

Table 1. 5 Dimensions of the ideological and political curriculum.

\begin{tabular}{|c|c|}
\hline Dimensions & Questions \\
\hline \multirow{6}{*}{$\begin{array}{l}\text { A } \\
\text { the philosophy } \\
\text { of the } \\
\text { ideological and } \\
\text { political } \\
\text { curriculum } \\
\text { (PIPC) }\end{array}$} & $\begin{array}{c}\text { A1 you have a clear understanding of the ideological and } \\
\text { political curriculum }\end{array}$ \\
\hline & $\begin{array}{l}\text { A2 the ideological and political curriculum helps to enrich } \\
\text { your knowledge structure and improve yourself }\end{array}$ \\
\hline & A3 the ideological and political curriculum is quite necessary \\
\hline & $\begin{array}{c}\text { A4 the ideological and political curriculum is popularized in } \\
\text { your college }\end{array}$ \\
\hline & $\begin{array}{l}\text { A5 the philosophy of the ideological and political curriculum } \\
\text { is introduced and advertised in your college }\end{array}$ \\
\hline & $\begin{array}{c}\text { A6 your college attach great importance to the students' } \\
\text { understanding of the objective and the role of the ideological } \\
\text { and political education }\end{array}$ \\
\hline \multirow{5}{*}{$\begin{array}{l}\text { B } \\
\text { the content of } \\
\text { the ideological } \\
\text { and political } \\
\text { curriculum } \\
\text { (CIPC) }\end{array}$} & $\begin{array}{l}\text { B1 the title of the ideological and political curriculum agrees } \\
\text { with the actual teaching content }\end{array}$ \\
\hline & $\begin{array}{c}\text { B2 the ideological and political curriculum is related to the } \\
\text { public concerns }\end{array}$ \\
\hline & $\begin{array}{c}\text { B3 there are no time conflicts between the ideological and } \\
\text { political curriculum and the specialized courses }\end{array}$ \\
\hline & $\begin{array}{c}\text { B4 you have the opportunity to practice through the } \\
\text { ideological and political curriculum }\end{array}$ \\
\hline & $\begin{array}{l}\text { B5 you have learned the cross-disciplinary courses through } \\
\text { the ideological and political curriculum }\end{array}$ \\
\hline
\end{tabular}

\begin{tabular}{|c|c|}
\hline & $\begin{array}{l}\text { B6 the ideological and political curriculum is theme-oriented } \\
\text { and involves many disciplines }\end{array}$ \\
\hline & B7 the ideological and political curriculum have rich content \\
\hline \multirow{8}{*}{$\begin{array}{l}\mathrm{C} \\
\text { the teachers of } \\
\text { the ideological } \\
\text { and political } \\
\text { curriculum } \\
\text { (TIPC) }\end{array}$} & $\begin{array}{l}\mathrm{C} 1 \text { the teachers pay attention to your ability to understand and } \\
\text { learn }\end{array}$ \\
\hline & C2 you have more interaction with the teachers \\
\hline & $\mathrm{C} 3$ the teachers have high teaching level in general \\
\hline & $\begin{array}{l}\text { C4 the teachers encourage the students to express different } \\
\text { ideas }\end{array}$ \\
\hline & C5 the teachers pay attention to the practice of team spirit \\
\hline & $\begin{array}{l}\text { C6 the teachers pay attention to the background knowledge } \\
\text { and the connection between the background knowledge and } \\
\text { the core knowledge points }\end{array}$ \\
\hline & $\begin{array}{l}\text { C7 the teachers pay attention to cultivate your mind and } \\
\text { inspirations }\end{array}$ \\
\hline & $\begin{array}{l}\text { C8 the teachers can inspire the connection between new } \\
\text { knowledge and the cognitive structure }\end{array}$ \\
\hline \multirow{9}{*}{$\begin{array}{c}\text { D } \\
\text { the } \\
\text { achievements of } \\
\text { the ideological } \\
\text { and political } \\
\text { curriculum } \\
\text { (PIPC) }\end{array}$} & $\begin{array}{l}\text { D1 your knowledge is expanded and your morality, } \\
\text { intelligence, aesthetics and rationality get developed }\end{array}$ \\
\hline & $\begin{array}{l}\text { D2 learn the ability to cope with and solve the problems } \\
\text { independently }\end{array}$ \\
\hline & D3 your aesthetic ability is improved \\
\hline & $\begin{array}{l}\text { D4 you have the deeper experience and more satisfaction in } \\
\text { your spiritual world }\end{array}$ \\
\hline & D5 you try to learn self-fulfilment and self-transcendence \\
\hline & D6 you know yourself multidimensionally \\
\hline & D7 you become more confident \\
\hline & $\begin{array}{c}\text { D8 you learn to analyze the domestic and international } \\
\text { political situation and events }\end{array}$ \\
\hline & D9 you become more confident \\
\hline \multirow{5}{*}{$\begin{array}{c}E \\
\text { the relevant } \\
\text { investigation of } \\
\text { the ideological } \\
\text { and political } \\
\text { curriculum } \\
\text { (RIPC) }\end{array}$} & E1 your college investigate your interests and needs \\
\hline & $\begin{array}{c}\text { E2 your college have interviewed and investigated the } \\
\text { students and teachers }\end{array}$ \\
\hline & $\begin{array}{l}\text { E3 your college offers the curriculum of many modules which } \\
\text { satisfies your needs }\end{array}$ \\
\hline & E4 your college can add more courses \\
\hline & $\begin{array}{l}\text { E5 the ideological and political curriculum can satisfy your } \\
\text { needs }\end{array}$ \\
\hline \multicolumn{2}{|c|}{$\begin{array}{l}\text { Every question in Table } 1 \text { can be answered from } 5 \text { choices which are } \\
\text { assigned by the values from the scores of } 1,2,3,4 \text { and } 5 \text {. The higher the } \\
\text { score is, the more positive the answer is. }\end{array}$} \\
\hline
\end{tabular}

\subsubsection{The selections of the questionnaire survey respondents}

The selections of the questionnaire survey respondents include the selection of the colleges and the students. Firstly, 9 colleges are selected according to the $\mathrm{Wu}$ Shulian's research on the classification of Chinese colleges as follows: Sichuan Post and Telecommunication College, Sichuan Water Conservancy Vocational College, Sichuan Vocational and Technical College of Communications, Sichuan Electromechanical Institute of Vocation and Technology, Sichuan College of Architectural Technology, Sichuan Engineering Technical College, Sichuan Electric Vocational and Technical College, Chengdu Textile College, Chengdu Agricultural College. Secondly, the college students from class of 2015 to Class of 2018 are selected.

\subsubsection{Information of the questionnaires}

The information of the questionnaires is seen in Table 2.900 questionnaires are issued. 836 are returned and 64 are missed. So the proportion of valid questionnaires is $92.9 \%$ and the missing proportion is $7.1 \%$. The freshmen, sophomores and juniors in the returned questionnaires are respectively 239, 206 and 391, which respectively account for $26.6 \%, 23.2 \%$ and $43.4 \%$.

Table 2. Information of the questionnaires.

\begin{tabular}{|c|c|c|c|c|c|}
\hline \multicolumn{2}{|c|}{ Questionnaires } & \multicolumn{3}{c|}{ Students } \\
\hline Issue and & No. & Proportion & Grade & No. & Proportion \\
\hline
\end{tabular}




\begin{tabular}{|c|c|c|c|c|c|}
\hline recovery & & & & & \\
\hline \multirow{2}{*}{ Issue } & \multirow{2}{*}{900} & \multirow{2}{*}{$100 \%$} & Freshman & 239 & $26.6 \%$ \\
\cline { 4 - 6 } & & & Sophomore & 206 & $23.2 \%$ \\
\hline \multirow{2}{*}{ Recovery } & 836 & $92.9 \%$ & Junior & 391 & $43.4 \%$ \\
\cline { 3 - 6 } & & Missing & 64 & $7.1 \%$ \\
\hline \multicolumn{2}{|c|}{$\begin{array}{c}\text { Every college is sent to } 100 \\
\text { questionnaires }\end{array}$} & Total & 900 & $100 \%$ \\
\hline
\end{tabular}

\subsubsection{Sampling method of the questionnaires}

The sampling methods of the questionnaires are random sampling method and stratified sampling method. Because the juniors have more experiences of attending the classes than the freshmen and the sophomores, the juniors can give more adequate answer in the questionnaires. Therefore, the proportion of the juniors in the questionnaires is the largest in order to improve the reliability of the data analyses.

\subsection{Statistical analysis}

\subsubsection{The tool and method of the statistical analysis}

This paper uses SPSS18.0 as the tool of the statistical analysis. The descriptive statistical analysis, the correlation analysis and the regression analysis are applied to analyze the questionnaires data.

\subsubsection{The reliability of the questionnaires}

The results of the questionnaires reliability adopting the testing method of statistical homogeneity reliability and $u$ sing Cronbach $\alpha$ coefficient as the testing standard can be seen in Table 3 .

As seen in Table 3, the whole reliability of the questionnaires is 0.906 which means very good; the reliability of TIPC and the reliability of CIPC are respectively 0.891 and 0.853 both of which mean good; the reliability of RIPC and the reliability of AIPC are respectively 0.748 and 0.725 both of which mean normal; the reliability of PIPC is 0.616 which means acceptable.

Table 3. The reliability of the questionnaires.

\begin{tabular}{|c|c|c|}
\hline \multirow{4}{*}{$\begin{array}{c}\text { Measuremen } \\
\text { t: } \\
\text { Cronbach } \\
\text { Alpha( } \alpha)\end{array}$} & $\begin{array}{c}\text { The whole reliability of the } \\
\text { questionnaires }\end{array}$ & 0.906 \\
\cline { 2 - 3 } & $\begin{array}{c}\text { Philosophy of the ideological and } \\
\text { political curriculum (PIPC) }\end{array}$ & 0.616 \\
\cline { 2 - 3 } & $\begin{array}{c}\text { Content of the ideological and } \\
\text { political curriculum (CIPC) }\end{array}$ & 0.853 \\
\cline { 2 - 3 } & $\begin{array}{c}\text { Teachers of the ideological and } \\
\text { political curriculum (TIPC) }\end{array}$ & 0.891 \\
\hline & $\begin{array}{c}\text { Achievements of the ideological } \\
\text { and political curriculum (AIPC) }\end{array}$ & 0.725 \\
\cline { 2 - 3 } & $\begin{array}{c}\text { The relevant investigation of the } \\
\text { ideological and political } \\
\text { curriculum (RIPC) }\end{array}$ & 0.748 \\
\hline
\end{tabular}

Note: $\alpha \in[0,0.59], \alpha \in[0.60,0.69], \alpha \in[0.70,0.79], \alpha \in[0.80,0.89]$ and $\alpha \in[0.90,1]$ respectively means a very bad reliability, a acceptable reliability, a normal reliability, a good reliability and a very good reliability.

\subsubsection{Correlation analysis}

As seen in Table 4, it is found that the correlation of the satisfaction degree of SIPC respectively between PIPC, CIPC, TIPC, AIPC and RIPC are all significant on the $1 \%$ significance level, which means that all the correlation are very strong.

Table 4. The Correlation between the Satisfaction Degree and PIPC, CIPC, TIPC, AIPC and RIPC

\begin{tabular}{|c|c|c|c|c|c|c|}
\hline \multicolumn{2}{|c|}{ Indicators } & PIPC & CIPC & TIPC & AIPC & RIPC \\
\hline $\begin{array}{c}\text { Degree of } \\
\text { Satisfaction }\end{array}$ & $\begin{array}{c}\text { Pearson } \\
\text { Correlation }\end{array}$ & 0.426 & 0.493 & 0.462 & 0.391 & 0.433 \\
\cline { 2 - 7 } & significance & $\begin{array}{c}0.000 \\
* * *\end{array}$ & $\begin{array}{c}0.000 \\
* * *\end{array}$ & $\begin{array}{c}0.000 \\
* * *\end{array}$ & $\begin{array}{c}0.000 \\
* * *\end{array}$ & $\begin{array}{c}0.000 \\
* * *\end{array}$ \\
\hline
\end{tabular}

Note: *** shows the $1 \%$ significance level.

\subsubsection{Regression analysis}

The satisfaction degree of SIPC is set as the dependent variable and PIPC, CIPC, TIPC, AIPC and RIPC are set as the independent variable.

Firstly, as seen in Table 5, the results of the satisfaction degree of SIPC shows that when the proportion of unclear is removed, the proportion of very satisfied and satisfied is very low accounting for only $26.2 \%$, the proportion of very unsatisfied and unsatisfied is very high accounting for more than $62 \%$.

Table 5. The Satisfaction Degree of the System of the Ideological and Political Curriculum (SIPC).

\begin{tabular}{|c|c|c|}
\hline Degree of Satisfaction & No. & Proportion \\
\hline very satisfied & 56 & $6.7 \%$ \\
\hline satisfied & 163 & $19.5 \%$ \\
\hline unclear & 97 & $11.6 \%$ \\
\hline unsatisfied & 317 & $37.9 \%$ \\
\hline very unsatisfied & 203 & $24.3 \%$ \\
\hline $\begin{array}{c}\mid 2 \\
\text { missing/valid } \\
\text { questionnaires }\end{array}$ & \multicolumn{2}{|c|}{$64 / 836$} \\
\hline
\end{tabular}

Secondly, as seen in Table 6 which shows the results of the analysis on the linear regression relationship between the satisfaction degree of the ideological and political curriculum and PIPC, CIPC, TIPC, AIPC and RIPC.As for the dependent variables, the $\mathrm{P}$ value of the coefficient of AIPC in model II and the P values of the coefficients of AIPC and RIPC in model III don't pass the significance test, so the coefficients are all removed from the final linear regression equation which finally includes the dependent variables of PIPC, CIPC and TIPC.

Table 6. The excluded variables in the linear regression equation.

\begin{tabular}{|c|c|c|c|c|}
\hline \multirow[t]{2}{*}{ Model } & \multicolumn{2}{|c|}{ Variables } & \multirow[b]{2}{*}{$\mathbf{t}$} & \multirow[b]{2}{*}{ Sig. } \\
\hline & $\begin{array}{c}\text { Dependent } \\
\text { Variable }\end{array}$ & $\begin{array}{c}\text { Independent } \\
\text { Variables }\end{array}$ & & \\
\hline \multirow{4}{*}{ I } & \multirow{9}{*}{$\begin{array}{c}\text { The } \\
\text { Satisfaction of } \\
\text { the } \\
\text { Ideological } \\
\text { and Political } \\
\text { Curriculum } \\
\text { (SIPC) }\end{array}$} & PIPC & 4.053 & $0.000 * * *$ \\
\hline & & RIPC & 3.078 & $0.002 * * *$ \\
\hline & & TIPC & 3.292 & $0.001 * * *$ \\
\hline & & AIPC & 2.113 & $0.035^{* *}$ \\
\hline \multirow{3}{*}{ II } & & RIPC & 2.463 & $0.014 * *$ \\
\hline & & TIPC & 2.277 & $0.023 * *$ \\
\hline & & AIPC & 1.585 & 0.113 \\
\hline \multirow{2}{*}{ III } & & AIPC & 1.143 & 0.253 \\
\hline & & RIPC & 0.814 & 0.416 \\
\hline
\end{tabular}

Note: $* * *$ and ${ }^{* *}$ respectively shows the $1 \%$ and the $5 \%$ significance level. 
Lastly, as seen in Table 7, the final linear regression equation is as follow:

$$
\mathrm{SIPC}=0.176+0.226 \mathrm{CIPC}+0.185 \mathrm{TIPC}+0.104 \mathrm{PIPC}
$$

It is concluded from the equation that the three variables PIPC, CIPC and TIPC are the factors affecting the satisfaction degree of the ideological and political curriculum. It is known from the final linear regression equation in which the coefficients of CIPC, TIPC and PIPC are respectively $0.226,0.185$ and 0.104 that among the affecting degree of the factors affecting the satisfaction degree, CIPC is the greatest followed by TIPC and PIPC is the least.

Table 7. The Final Linear Regression Equation.

\begin{tabular}{|c|c|c|c|c|c|}
\hline \multirow[b]{2}{*}{ Model } & \multicolumn{2}{|c|}{ Variables } & \multirow[b]{2}{*}{ Coefficient } & \multirow[b]{2}{*}{$\mathbf{t}$} & \multirow[b]{2}{*}{ Sig. } \\
\hline & $\begin{array}{c}\text { Dependent } \\
\text { Variable }\end{array}$ & $\begin{array}{c}\text { Independent } \\
\text { Variables }\end{array}$ & & & \\
\hline \multirow{2}{*}{ I } & \multirow{9}{*}{$\begin{array}{c}\text { The } \\
\text { Satisfaction } \\
\text { of the } \\
\text { Ideological } \\
\text { and } \\
\text { Political } \\
\text { Curriculum } \\
\text { (SIPC) }\end{array}$} & Constant & 0.527 & 2.596 & $0.001 * * *$ \\
\hline & & CIPC & 0.318 & 8.371 & $0.000^{* * * *}$ \\
\hline \multirow{3}{*}{ II } & & Constant & 0.163 & 1.147 & 0.252 \\
\hline & & CIPC & 0.247 & 6.853 & $0.000^{* * *}$ \\
\hline & & PIPC & 0.115 & 4.206 & $0.000^{* *}$ \\
\hline \multirow{4}{*}{ III } & & Constant & 0.176 & 1.082 & 0.280 \\
\hline & & CIPC & 0.226 & 4.737 & $0.000 * * *$ \\
\hline & & PIPC & 0.104 & 3.869 & $0.000^{* * *}$ \\
\hline & & TIPC & 0.185 & 2.372 & $0.018^{* * *}$ \\
\hline
\end{tabular}

Note: ${ }^{* * *}$ and ${ }^{* *}$ respectively shows the $1 \%$ and the $5 \%$ significance level.

\section{Conclusion}

Because of the characteristics of the hierarchy and classification of Chinese colleges, the status of SIPC in general education in Chinese colleges of science and technology is the lowest. Through the analysis on the questionnaire survey, it is found that the 3 factors --CIPC, TIPC and PIPC affecting SIPC in the colleges of science and technology pass the significance test with the affecting degree from the least to the greatest. This means that besides the focus on the most essential factor --CIPC, the importance of the role of TIPC should be stressed and the introduction of PIPC should be enhanced and the publicity of PIPC should be strengthened. Furthermore, the reasons why the 2 factors --- AIPC and RIPC don't show the significant influence on SIPC should be thought about. Moreover, the setting of the ideological and political curriculum should be improved by other dimensions besides the 5 dimensions mentioned in this paper in order that the satisfaction degree of SIPC will be possibly improved and the role of SIPC in general education will be better played.

\section{References}

1. S. L Wu, SSM of S.\& T., 10, 26-30 (2002).

2. T. Edward, Clark, JR., Designing \& Implementing an Integrated Curriculum: A Student-Centered Approach (1997).

3. J. Miller, The Holistic Curriculum (2001).

4. A. Levine, $A$ Handbook on Undergraduate Curriculum (1978).

5. V. Smith, New Dimension for General Education in Higher Learning in America, 1980-2000 (1992).

6. G.E. Muller, The Weaning of General Education (1988).

7. H. Bodenhorn, JEE, 28, 323-336 (1997). 